\title{
NOMINALIZATION: A CASE STUDY OF
} LINGUISTIC TEXT CONVENTIONS IN

\section{COMPARABLE AND PARALLEL TEXTS: ENGLISH AND NORWEGIAN}

\author{
BERGLJOT BEHRENS \\ University of Oslo
}

\section{A B S T R ACT}

A case study of highly comparable scientific texts in English and Norwegian demonstrates important differences in use of a number of textual features. of particular interest is the use of event-nominalizations, English showing a markedly higher frequency of use than Norwegian. A Multitranslation corpus of Norwegian professional translators demonstrates leanings towards the English text conventions in their translations, deviating from text conventions used by Norwegian professionals in the same scientific field. The present article takes the degree of complexity in nominalizations in the comparable texts into account and discusses the variability of the translations in view of Norwegian conventions established on the basis of quantitative measures. The study indicates that translators follow different linguistic strategies of scientific text production than professional scientists in the field.

\section{[1] INTRODUCTION}

Nominalizations enable a writer to classify events as abstract things and predicate over them. This very useful conceptual and linguistic operation is not least made extensive use of in all scientific texts.

When the same nominalization structures are available in two languages, such as (for my purpose here) English and Norwegian, would there be any reason for not mapping a nominalization in a source text into a parallel nominalization in a translation?

Students of translation tend to answer the question negatively, and the translation teacher tends to suggest the opposite (personal experience). The translator is advised to look for formulations that follow the text conventions of the target language, to make the target text read as fluently as possible ${ }^{1}$. This piece of advice relates to non-fictional prose in particular. In order to make the advice to the

[1] The debate over fluency in literary translation, particularly Lawrence Venuti's perspectives on style in translated literature (Venuti 2004), is irrelevant for the claim made here. 
translation student more precise, then, possible linguistic constraints on forming nominalizations in the language pair need to be spelled out, but beyond that we need to establish the text conventions in the two language cultures, and by that I mean here the writing conventions of the people working in the same field or domain and using the same register.

In this paper I report on a case study of the language used in highly comparable scientific texts in English and Norwegian, with a particular focus on the use of nominalized structures. The English text appears with 10 Norwegian translations in the Multitranslation sub-corpus of OMC (Oslo Multilingual Corpus). Beyond Johansson (2004), the non-fictional part of this corpus has not been studied in any detail before in any given publication that I know of. The addition of Norwegian source texts of the kind I supply here is needed to make good use of the corpus data for translation research. I will argue for this view in section [3]. Two Norwegian texts have been selected for comparison with the English source text, both in the same field and of the same register. Features of these texts are then compared with the translations in the corpus. The corpus is admittedly small, my pilot study is even smaller, but I hold that a descriptive case study of this sort should indicate a trend that is worth pursuing.

The texts in the corpus deal with research done in the social science domain, more specifically they aim to make some empirically based claims about infant communication from a psychological perspective. They are written by highly qualified researchers in the same field of psychology, and the Norwegian texts both make references to the writer of the English text. This makes my small corpus highly comparable for the contrastive study of text conventions, and a useful corpus for comparing the language of Norwegian translation (from English) against Norwegian source text conventions.

The paper is structured as follows:

In section [2] I report briefly on a contrastive corpus study of nominalization in English and Norwegian popular science texts, to present some major trends found in translation. In section [3] I present the types of nominalization found in a small excerpt of the scientific text in the Multitranslation Corpus of the OMC, and report on my quantitative findings. I then extend the data and my analysis of the textual features of the English and the two Norwegian original texts for comparison (section [4]). The textual features of the Norwegian texts are subsequently used as my basis for a discussion of the variability in the translations of the English source (section [5]).

[2] A CONTRASTIVE STUDY OF NOMINALIZATION IN ENGLISH AND NORWEGIAN

Nordrum's PhD work on lexical nominalization in English, Swedish and Norwegian (Nordrum 2007) is a very interesting study of constraints on nominalization 
in the three languages, based on manually retrieved examples from the English non-fiction subcorpus of ENPC and ESPC ${ }^{2}$. Nordrum $(2007,6)$ comments that manual retrieval had to be chosen for the very reason that nominalizations come in so many shapes and forms that deciding on all the correct search items would be difficult. Her data consist of 589 lexical nominalizations in a set of seven nonfictional English texts, a total of 76000 words $^{3}$. The data set, then, is one-directional: contrasting English sources and Norwegian translations ${ }^{4}$.

Nordrum's study demonstrates that English and Norwegian generally have the same structural possibilities to form nominalizations. A quantitative comparison, however, shows that Norwegian translations follow the same structure as the English source in only $65-70 \%$ of the cases. There are basically two main trends to be noted:

Complex nominalizations after prepositions, such as in (1), (Nordrum 2007, ch. 4 (9)), are generally translated as clauses in Norwegian:

(1) for the team's use of the farm's machinery

for at gruppen hadde fått benytte brukets maskinpark

for-that-the group-had-got-use-the farm's-machinery

English does not allow clauses after prepositions; Norwegian allows nominal thatclauses as well as infinitive clauses after prepositions. A clause-structure after the preposition, as in (1) is quite common in Norwegian, although a nominalization in this linguistic environment is not syntactically precluded. Thus the phrase in (1) would not be syntactically ill-formed as a nominalization in Norwegian, viz.:

(2) for gruppens bruk av gårdens maskinpark

for-the team's-use-of-the farm's-machinery

The question is whether a clause form after prepositions is also the preferred form in our Norwegian scientific texts.

The other trend taken up by Nordrum is that complex nominalizations in THEME-positions in English show up as clauses in Norwegian translations, such as in (3), (Nordrum 2007, (ch. 4 (8)):

(3) Mikhail Gorbachev's endorsement, when in power, of the individual farmer's right to supplement his income from selling his privately grown fruit and vegetables harks back to his own childhood memories of how vital this tiny

[2] ENPC: The English-Norwegian Parallel Corpus, a major subcorpus of OMC: The Oslo Multilingual Corpus. ESPC is the English-Swedish Parallel Corpus, designed and collected on the basis of the ENPC design.

[3] By lexical nominalization the author means deverbal nominals to the exclusion of more clausal forms like gerunds, infinitives and finite nominal clauses. I use the more general term nominalization in this sense.

[4] The Swedish translations in Nordrum's thesis are disregarded in my paper, for reasons of relevance. 
extra stipend could be to a rural family. (ENPC/ESPC MAW1)

Noe av det første Mikhail Gorbatsjov gjorde da han kom til makten var å understreke bøndenes rett til å spe på inntekten ved å selge den frukten og de grønnsakene de hadde dyrket selv. (ENPC MAW1T)

"One of the first [things] MG did when he came into power was to endorse the farmers' right to supplement the income by selling the fruit and the vegetables they had cultivated themselves."

The Norwegian translation has split the English source sentence into two, only the translation of the theme part of the source is shown in the example.

This brief synopsis of major findings in Nordrum's thesis does not reflect her rich and detailed contrastive study of nominalizations in the three languages. For my purposes here, however, it reports on two major trends in English-Norwegian translation of non-fictional text.

A derivational aspect of nominalization in the two languages should also be taken into account in a contrastive study: Nominalizations vary in their degree of lexicalization. The less derivable the meaning of the deverbal noun is from the meaning of the verb it stems from, the more lexicalized it is (Andersen 2007). Less lexicalized nominalizations denote actions only, and are thus closest to the verbal meaning, but as they lexicalize, they become more polysemous, taking on result meanings and then possibly also product meanings. -ing nominalization is the most productive derivation of verbs to nouns in present day English and Norwegian. Consequently, -ing nominalized items are also expected to be less lexicalized. But an item may have gone through stages of lexicalization in one language only, which means that translation into the same form may prove infelicitous if it is less lexicalized in the target language.

In the following presentation of my data I will make a simple classification of the nominalizations in my corpus, based on their underlying complexity, but also on their nominal form. This means that my classification is not totally in accordance with the classical classification of Grimshaw (1990), which is more elaborate, yet also controversial, and not needed for the present account ${ }^{5}$.

\section{[3] A PILOT STUDY OF THE MULTITRANSLATION CORPUS IN OMC}

The Multitranslation Corpus in OMC consists of two English source texts, one literary text and one social science text, each of about 6000 words, with translations from ten professional translators. The corpus includes a first draft translation as well as the end products, both of which are electronically available in OMC. My quantitative study of the science text is based on manual counts, for the same rea-

[5] See footnote 6 . 
sons as mentioned by Nordrum (see above). To make the study manageable for a pilot, I have selected five translations randomly.

Social science expository texts differ from narratives in their linguistic features. Expository texts are generally characterized by being formal in style, the present tense is the 'norm', the sentences are often quite nominal-based rather than verb-based, and the texts have a high level of complex sentence structure (Schleppegrell 2006). Nominalizations in expositories are therefore expected to show up in high numbers compared to narratives.

The English source text is written by Professor Colwyn Trevarthen. The author has agreed to have the text translated and used in this corpus. The following is a small excerpt of 70 words from the text, nominalizations are set in italic:

(4) Infants adapt to expressions of the mother. Young infants respond adaptively to a wide range of human signals and these responses demonstrate their elaborate perception of persons. Infants mimic expressions of adults. Maratos (1973) has shown that infants under one month of age may imitate pitch and duration of sounds, tongue protrusion and mouth opening, but she did not obtain imitation of head rotation, babbling or leg displacement at this age.

The nominalizations in this excerpt are all syntactic objects in the sentences. They differ in their syntactic build-up in the following way:

(i) Simple nominalizations ${ }^{6}$, such as responses (from the verb respond) and babbling (from the verb babble)

(ii) Compound nominalizations, such as tongue protrusion (from protrude the tongue), mouth opening (from open the mouth), similarly head rotation and leg displacement.

(iii) Complex nominalizations reflecting larger syntactic structures, such as

(a) their elaborate perception of persons (They perceive persons ?elaborately) (Subj-V-Obj)

(b) expression of adults (Adults express X) (Subj-V)

(c) imitation of head rotation (X imitate head rotation) (V-Obj (Obj-V))

The English 250 word excerpt used for a first-hand analysis includes the excerpt in (3) above. It contains a total amount of 26 nominalizations, only two of which

[6] My terms 'simple' and 'complex' deviate from Grimshaw's definition of these terms. Grimshaw's 'simple' event nominals do not require an expression of their arguments, while 'complex' nominalizations do. My classification is based on the form in which the relevant nominals appear, ie they are simple if they appear without expression of any participants. See also McNally \& Espinal (2011) for a similar deviation from the Grimshaw classification. 
form the subject of a clause: one simple nominalization, the response, and one complex, the search for a desired pattern of movement.

Generally, translations vary with respect to the norms they follow, along a scale from target orientation to source-orientation (Toury (1995); Teich (2000); House (2001)), but little has been done to spell out the textual norms of different genres on an empirical basis in a Norwegian-English perspective. Teich, in her work on variability in text conventions in English and German, demonstrated a very interesting approach to linguistically oriented translation studies, the basic idea of which I follow in the present study: In order to make empirically based claims about translation, we need first to establish the linguistic features of comparable texts in the two languages, and only then measure the norms of existing translations. The same view is advocated in Blum-Kulka's paper on coherence in translation, who claims that

... [it] is necessary to first carry out large scale contrastive stylistic study (in a given register) to establish cohesive patterns in SL (the source language) and TL (the target language), and then to examine translations to and from both languages to investigate shifts in cohesive levels that occur in translation. (Blum-Kulka 1986, 33)

My study is not large scale in Blum-Kulka's sense, but a beginning in her vein. I have looked into two scientific articles about infant communication produced by two Norwegian professors in the field. The articles deal with very similar topics, and both make reference to the works of the author of the source text. One article (Norw1) is published in a scientific journal (Smith), the other one, (Norw2), as a chapter in a book (Braathen 2004). A preliminary investigation of a comparable size of 250 words of each text has revealed a number of features that diverge from the features of the English excerpt, as shown in table 1 on the facing page.

The text patterns in the English text and the two comparable Norwegian texts differ in ways that may be significant for different conventions of text construal in the two languages (given this domain and register). Whereas the English text excerpt has 19 clauses in this span, the Norwegian texts both have almost twice as many clauses, and the number of nominalizations is almost three times as high in the English text compared with the comparable Norwegian texts. Not unexpectedly, the Norwegian texts are not identical, some notable differences being the infinitival complements to preposition used in Norw1 (prep-comp infinitive) and the somewhat higher number of subordinate clauses in Norw1 compared to Norw2. But the two are very similar in their use of nominalizations and their total number of clauses. The results of this small scale case study already indicate that the text conventions in Norwegian and English differ: English places more propositional information in condensed, nominal form than Norwegian. 
TABLE 1: Characteristic features of the English and Norwegian comparable text excerpts

\begin{tabular}{lrrr}
\hline & English & Norw 1 & Norw 2 \\
\hline Total no of clauses & 19 & 30 & 27 \\
Main clauses & 12 & 9 & 11 \\
Adverbial clauses & 3 & 6 & 3 \\
Nominal clauses & 2 & 6 & 5 \\
Relative clauses & & 3 & 3 \\
Coordinated clauses & & 2 & 4 \\
Comparative clauses & & & 1 \\
Prep-comp infinitive & & 4 & \\
Other non-fin clauses & 2 & & \\
Nominalizations & 26 & 9 & 10 \\
\hline
\end{tabular}

In comparison, the translators' use of nominalizations in the five (randomly chosen) translations (T1-T5) of the English excerpt distribute as in table 2:

TABLE 2: The use of nominalizations in five (randomly chosen) translations of the 250 word excerpt of Trevarthen's text

\begin{tabular}{lrr}
\hline & Translation 1st version & Translation final version \\
\hline T1 & 14 & 14 \\
T2 & 11 & 11 \\
T3 & 25 & 24 \\
T4 & 23 & 23 \\
T5 & 17 & 15 \\
\hline
\end{tabular}

The table 2 shows that the translators vary considerably in their translation choices. Furthermore, they do not make many changes in their revisions; only two translators have reduced the number of nominalizations in favor of other structures. Disregarding the two translators who have almost the same number of nominalizations in their texts as the source text, the average number of nominalizations in this small excerpt of translations makes up just 50 per cent of the nominalizations of the source text. This is lower than the results from Nordrum's much larger study, which indicated between $65-70 \%$ match, yet somewhat higher than the results in table 1 . One might be curious as to the quality of each of the five translations: Are the translations with fewer nominalizations better translations? We do not have clear, objective measures of translation quality, but a closer study of the translations relative to the conventions of comparable texts may give us an indication. This is taken up in section [5]. 
In order to make the study more representative, a quantitative analysis of a larger size text of 2500 words is presented in the next section.

\section{[4] EXPANDING THE DATA}

In order to check whether the results of the pilot study is just a coincidence, I have made a quantitative study of the textual features of larger excerpts of 2500 words each of the English original and the two texts by the same Norwegian authors. Norw1 is the same text as analyzed above; Norw2 is another text also on the same topic, (Braaten 1996) ${ }^{7}$. Nominalizations are quantified according to type: a distinction is made between simple, compound and complex nominalizations, as exemplified on the basis of example (3) in section [3] above.

The English text excerpt consists of 224 clauses. The number of clauses in the Norwegian texts is higher, amounting to 263 and 255 clauses in Norw1 and Norw2 respectively. Does this difference reflect the use of nominalizations in the three texts? The clause types and their frequencies in the texts are listed in table 3 below. The relative number of main clauses is similar, so the difference lies in the relative use of subordinate clauses. On the assumption that complex nominalizations are used with more 'ease' in English than in Norwegian to refer to given actions and events, as suggested by Nordrum's study, this kind of information must find other expressions, such as subordinate clauses, in Norwegian. This would be expected on the assumption that subordinate clauses 'compete' with nominalizations in being expressions for given actions and events.

The distribution of clauses in the three texts shows very clearly that clauses introduced by prepositions, which do not appear in English, are frequent in the Norwegian texts. Furthermore, nominal clauses figuring as arguments appear in both texts, as might be expected, but infinitive clauses used as arguments appear in the Norwegian texts only, although such structures are not precluded in English. Finally, there is a notable difference in the use of relative clauses, which appear more often in the Norwegian texts. We may hypothesize that prepositional phrases with infinitives, infinitival arguments and relative clauses are Norwegian alternatives to complex nominalizations in English.

We can now move on to nominalizations in the three texts.

\section{[4.1] Nominalizations in the expanded data set}

The English text has a total of 116 nominalizations, disregarding the repetition of the most frequent simple nominalizations, such as movement (31 tokens), expression (30), cooing (7), smiling (5) and opening (5). Among the nominalizations we find

[7] The choice of a different text by this author is motivated by the fact that the larger study was performed at a time when his first text was no longer available to me. However, using a different text by the same author makes the study more representative. 
TABLE 3: Characteristic clausal features of the English and Norwegian comparable text excerpts, each of 2500 words

\begin{tabular}{lrrr}
\hline & English & Norw 1 & Norw 2 \\
\hline Total no of clauses & $\mathbf{2 2 4}$ & $\mathbf{2 6 3}$ & $\mathbf{2 5 5}$ \\
Main clauses & 116 & 96 & 117 \\
Coordinated clauses & 13 & 15 & 21 \\
Relative clauses & 25 & 43 & $\mathbf{3 8}$ \\
Postmodifying participles & 1 & 8 & - \\
Nominal finite clauses(arguments) & 23 & 24 & 12 \\
Nominal infinitives & 0 & 10 & 14 \\
Adverb clauses, finite & 14 & 19 & 17 \\
Adverb clauses, participial & 12 & - & - \\
Adv clauses, infinitive & 9 & 17 & 10 (Prep-intro) \\
Prep-that-clause-adv & & 7 & 3 \\
Prep- infinitive-postmod. & & 11 & 15 \\
Prep-that-clause postmod. & & 9 & \\
Other clauses & 12 & 4 & 8 \\
\hline
\end{tabular}

- 25 occurrences of compound nominalizations, e.g. intersubjectivity mirroring, lip tightening, mouth configurations;

- 30 occurrences of of-nominalizations reflecting either V-Obj structures, e.g. the study of these patterns or V-Subj structures e.g. the expression of adults, including examples with possessive determiners, e.g. their elaborate perception of persons (totaling 5), and compound nominal heads, e.g. the mouth movements of infants;

- finally, 10 occurrences of more complex structures, viz. some examples of gradual complexity:

(5) the search for a desired pattern of movement

(6) the formulation of a new focus for visual attention

(7) the development of deliberate well-aimed visual orientation to the mother's eyes

(8) the association of lip pursing or tongue-protrusion with index-finger pointing or index-thumb closing

Comparing the English text with the two Norwegian text excerpts of the same size, we obtain the results shown in table 4 . The percentages in the table reflect 
TABLE 4: The distribution of compound and complex nominalizations in the three text excerpts of 2500 words each

\begin{tabular}{lrrrr}
\hline & English & Norw 1 & Norw 2 & $\%$ \\
Compound & 25 & 5 & 10 & $20 / 40$ \\
Poss. Det. & 5 & 7 & 13 & $>100$ \\
More complex & 40 & 29 & 19 & $72 / 47$ \\
Sum & 70 & 41 & 42 & $58 / 60$ \\
\hline
\end{tabular}

the percentage of nominalizations in each of the Norwegian texts as compared with the English text. One difference observed is that the possessive determiners in the English text are all pronominal, while the Norwegian possessive determiners are all full noun phrases. English examples are: their expression, their first appearance. Norwegian examples are: mødrenes ytringer, barnets adferd (the mothers' expressions, the child's behavior). Moreover, compounds and more complex nominalizations appear with much higher frequency in English. The sum results of non-simple nominalizations in the texts show a lower frequency of use in Norwegian relative to English (average 59\%) than Nordrum's translation corpus study indicated (65-70\%). It is unclear, however, whether this difference is significant, not least in view of the different size of data, but it may be an indication that the Norwegian texts in Nordrum's study, which are translations, are colored by a certain amount of structural transfer from English, making the texts stylistically marked. In the following discussion of the findings, I will consider the syntactic function of the nominalizations.

One important difference in the texts is the level of complexity found in the nominalizations relative to their syntactic position in the sentence. For lack of space I will only consider subject positions here. Nordrum's observation that long, complex nominals in subject position in English appear as clauses in Norwegian translations, correlates with the findings in this comparative study: The most complex nominalizations in subject position in the Norwegian texts are nominalizations modified by prepositional phrases with clausal, not nominal, complements, such as (9):

(9) Barnets tilbøyelighet til å se opp mot den voksne og deretter tilbake på objektet viser at ...

The child's-tendency-to-to-look-up-towards-the-adult-and-then-back-on-the object-shows-that ...

of-phrase modifications (subject or object) in Norwegian nominalizations (i.e. avphrases) appearing in subject positions are few. The first text I looked at (Braaten 2004) had one in a text excerpt of 3000 words: 
(10) Avdekking av et slikt samspillmønster med protodialog... Uncovering-of-a-such-interaction pattern-with-protodialogue...

The other text by Bråten (Norw2) also had one only, in this case appearing after the finite verb, and not as the sentence opening:

(11) Uten det ville for eksempel Kuguimutzakis $(1993,1994)$ funn av tidlig lydmessig etterligning og endog imitering av voksnes ansiktsgester hos 15 minutter gamle spedbarn kunne blitt møtt med vantro og avvisning.

Without-it-would-for-example- Kuguimutzaki's (1993, 1994) finding-of-earlysoundwise-emulation-and-even-imitation-of-adults'-facial gestures-in-15 min-oldinfants-could-be-met-with-disbelief-and-renunciation.

The other complex subject phrases containing a nominalization in this text (4 in all) are nominalizations modified by other prepositional phrases, and would not translate into Subject-Verb structures or Verb-Object structures.

Norw 1, the other Norwegian text, is somewhat more 'liberal' in allowing Norwegian equivalents to of -nominalizations reflecting a Verb-Object structure, or even a Subj-Verb-Object, in Subject position: A total of five examples appear in the text ${ }^{8}$ :

(12) Utviklingen av koordinert oppmerksomhet er av utviklingsmessig betydning. The development-of-coordinated-attention-is-of-developmental-importance.

(13) Anvendelse av atferdsritualer...

Use-of-behaviour rituals...

(14) Prediksjon av reseptiv språkutvikling...

Prediction of receptive language development...

His next example appears as the subject of an extraposed that-clause subject of the sentence: again indicating that the language resists or at least disprefers complex nominalizations in sentence initial theme position:

(15) Det er sannsynlig at koordineringen av oppmerksomhet hjelper barnet til ... It-is-reasonable-that-the coordination-of-attention-helps-the child-to ...

The final example shows a complex nominalization forming the subject of a Norwegian that-clause functioning as the complement of a preposition (om: Eng about).

[8] For lack of space I have not taken up questions relating to the (non-)determination of the nominalizations, although this is an interesting issue since lack of or type of determiner also is an indication of the stage of lexicalization (Andersen 2007). 
The preposition phrase itself (om at + clause, i.e. about-that + clause) functions as a complement to the subject noun phrase of the sentence ${ }^{9}$.

(16) En tilsvarende hypotese om at barns initiering av felles oppmerksomhet er unikt relatert til utviklingen av talespråk ble også bekreftet A-similar-hypothesis-about-that-children's-initiating-of-mutual-attentionis-uniquely-related-to-the development-of-oral-language-was-alsoconfirmed.

In comparison, there are 25 complex nominalizations in subject position in the English text, 20 of which are subjects of main clauses, the rest are subjects of thatclauses.

In sum, then, we have observed notable differences in the complexity of nominalizations in the two languages as they are used in this domain and register. Complex nominalizations do appear, although sparingly, in subject position in Norwegian texts, yet the texts indicate a constraint that the head nominalization be followed - at least preferably - by at most one post-modifying prepositional phrase reflecting the Object of the verb underlying the nominalization. There is not a single example in the Norwegian texts of an of-nominalization reflecting a Verb-Subject structure, as opposed to what we observed in the English text.

\section{[5] NOMINALIZATIONS IN THE NORWEgIAN TRANSLATIONS OF THE ENGLISH SOURCE TEXT}

We shall now take a closer look at the short translation extracts of the English source text that I presented in section [3], and consider the nominalization structures chosen, in view of the general findings based on the comparable texts analyzed above.

We have seen that a general reduction of nominalizations will be expected to be a good solution, compensated for not least by infinitival structures in different syntactic constellations. But we have also seen that the internal complexity of the nominalizations relative to their syntactic position in the sentence is of major importance for a felicitous Norwegian translation of this kind.

The five translators of the English text formed two groups, one with almost the same number of nominalizations as the source text (T3, T4), the other three (T1, $\mathrm{T} 2, \mathrm{~T} 5)$ with a 50 per cent reduction. How do their choices relate to the general findings for Norwegian originals?

In the small English extract of 250 words, two complex nominalizations, both with an underlying Verb-Object structure, appear as Subjects of the sentence:

[9] It is interesting to observe that Norwegian does not generally allow that-clauses to modify nouns without a preposition relating it to the noun. This difference deserves closer attention, but falls outside the scope of the present paper. 
(17) The search for a desired pattern of movement must be regulated by a process of matching. ..., (but) some kind of adjustment of the 'image' to be made to that of a movement seen must be taking place in the brain.

Both examples are solved by the use of parallel nominalizations by all the translators. The direct mapping of the simpler one, (17), is felicitous in parallel translation. The second one, on the other hand, has obviously troubled the translators: It appears as the subject of a coordinated clause, and is internally a complex embedding of nominalizations: the modifying of-phrase contains a comparison of two abstract entities ('image' and movement) which are themselves modified by nonfinite clauses (to be made/ seen). T3 has direct mappings with two av-phrases and miss out on the postmodifying non-finite clauses, which is hardly a felicitous rendering. T4 has chosen different prepositions, which makes the relations clearer, and has furthermore divided the sentence into two. In this translation operation the information in one of the postmodifying clauses has been lost.

$\mathrm{T} 1$ and $\mathrm{T} 2$ follow the same pattern as $\mathrm{T} 3$ and $\mathrm{T} 4$.

$\mathrm{T} 5$ is the only translator who has managed to retain the information in the postmodifying non-finite clauses, in the form of relative clauses. This correlates with our general quantitative study of the Norwegian texts above: relative clauses are used with a notably higher frequency in the Norwegian texts than in the English text. Yet, T5 has retained the nominalization with the two av-phrases, which goes against the general findings in the Norwegian comparable texts.

The quantitative study made here, correlates with the trends reported from Nordrum's study and suggests that the translators should consider clausal solutions and possibly sentence division in cases of complex embeddings of nominalizations in English. In this case repetitions of the concept expressed in the English nominalization 'adjustment' might be a solution that allows a structure more in line with our general findings for this Norwegian genre, cf. a suggested alternative in (19):

... men en slags mental justering må finne sted: "bildet" av en bevegelse som skal utføres må justeres til et bilde av en allerede utført/erfart bevegelse.

... but some kind of mental adjustment must take place: the 'image' of a movement which shall/is to be made, must be adjusted to an image of an already experienced movement.

of-nominalizations with a simple head and an underlying Verb-Subject structure are successfully translated by nominalizations with a possessive Noun Phrase determiner, such as morens uttrykk, voksnes uttrykk (the mother's/adults' expression) for 
expressions of the mother/adults'. A Subject-Verb-Object structure such as in (20), on the other hand, shows divergent solutions by the translators: ....and these responses demonstrate their elaborate perception of persons.

T1 and T5 have successfully opted for a that-clause with the possessive determiner of the source as its subject (the different adjectives chosen by the two translators are more or less synonymous):

(21) og denne responsen viser at de har en nøyaktig og detaljert/nyansert oppfatning av mennesker.

and-this-response-shows-that-they-have-a-consise-and-detailed/elaborateperception-of-persons.

When a nominalization has been chosen $(\mathrm{T} 2, \mathrm{~T} 4)$, the subject (possessive determiner) has been dropped in T2, but retained in T4. Our general analysis of Norwegian originals has not demonstrated a preference for one or the other.

Compounds were found to be notably less frequent in Norwegian compared to English in the comparable texts, irrespective of syntactic position in the sentence. The English text excerpt considered here is interesting for the very reason that it appears with a number of compounds with an underlying Object-Verb structure, such as leg displacement, head rotation, hand opening, mouth opening, tongue protrusion, jaw drop, all typically lexicalized reifications of the actions observed in the infants studied, and particular for the topic of the texts. The Norwegian comparable texts also refer to these actions, not in terms of specifications of the type of movements, such as 'openings', 'displacements' , or 'protrusions', but by a more general, lexicalized nominalization: bevegelser (movements). No action nominalization of a more specified type-of-movement verb occurs. Non-lexicalized nominalizations are potential forms, but they would be neologisms, and would not reasonably occur in compounds, since compounds name established concepts (at least within the specialized field of science). A verbalization of the source nominalization, therefore, might be a more felicitous alternative. Let us look at the translators' solutions of the following example:

... but she [the researcher] did not obtain imitation of head rotation, babbling or leg displacement at this age. (Relating to video observations)

T1 retains the first two nominalizations, but changes the last one into an infinitive. This change in a list of coordinated set of actions seems to break with a principle of keeping coordinated elements of the same form. As this principle has not been considered for the Norwegian comparable texts, it is at this point impossible to judge the translator's solution on the basis of the general findings. I do not consider it a felicitous solution. 
T2 verbalizes the nominalizations, which is in accordance with the general findings of the comparable texts.

T3 generalizes the last compound, which is also in accordance with the observations made in the study above.

$\mathrm{T} 4$ and $\mathrm{T} 5$ retain the compound head rotation as a compound (lexicalized in Norwegian), but change the last compound to a complex nominalization.

The translations also differ in their choice of expression for the head of the nominalization. This is where the question of lexicalization becomes even more relevant: Does the lexicalized deverbal nominal 'imitation' in English denote an action or a result? It appears without a determiner and is followed by the preposition of, which might indicate an action reading; on the other hand, the context suggests a result which the researcher did not obtain.

$\mathrm{T} 3$ and $\mathrm{T} 4$, which show the highest frequency of nominalizations among the five texts, seem to have interpreted the nominalization without consideration of the previous cotext: they lean on the form of the complex nominalizations and map it into a non-lexicalized -ing nominalization, in spite of the fact that Norwegian also has the result nominal imitasjon. Only $\mathrm{T} 5$ has come up with this choice, and has also found a more general lexicalized compound nominalization for 'leg displacement', which seems the most felicitous solution of the three:

(23) T3: ... men hos barn i denne alderen fikk hun ikke etterlikning av hodevridning, skravling eller fotbevegelser.

but-with-children-at-this-age-got-she-not-imitating-of-head rotationbabbling-or-foot movements.

(24) T4: Men hun avdekket ikke imitering av hoderotasjon, babling eller flytting av ben i denne alderen.

But-she-uncovered-not-imitating-of-head rotation-,-babbling-or-movingof-feet-at-this-age.

(25) T5: Hun fant ikke imitasjon av hoderotasjon, babling eller forandring i benstilling i denne alderen.

She-found-not-imitation-of-headrotation-babbling-or-changes-in-leg position-at-this-age

\section{[6] CONCLUSION}

My detailed study has indicated that the text conventions in English and Norwegian differ in this field and register, with more sentential expressions for given actions and events in Norwegian compared to English. The analysis of the small excerpts from the five translations also indicates that the translators do not have a fully internalized model of the source text conventions of this text domain. My analysis suggests that the translators would benefit from considering clausal so- 
lutions and possibly sentence division in cases of complex embeddings of nominalizations in English, and would be advised to verbalize complex nominalizations in sentence openings. My quantitative results on nominalization in original non-fictional text in Norwegian also suggest that Nordrum's contrastive study is somewhat biased by the fact that it is based on translation corpora. On the other hand, my corpus is small, so analysis of larger quantities of text is needed to make firmer claims.

Finally, I would like to reflect more generally on the translation products: The translator is always under a multitude of constraints, linguistic as well as social. Such constraints affect the translated products. Social facts, such as the kinds of text that are selected for translation in a country, the existence and availability of comparable texts in the target language, the time allowed for producing the translation and the money offered for the task, as well as the type of professionalism held by the translators, all affect the end product. But linguistic factors are all pervasive, and the model of language or text that translators map their translations into has as yet been highly under-investigated. My case study here is a beginning. Comparable texts are manifestations of a model of the language used, and an awareness of their properties can be very useful not only for more objective assessment of translations, but also, I would claim, for the translator to activate the text conventions of the field and register in the target language.

The translators $\mathrm{T} 1$ to $\mathrm{T} 5$ have made their translations under uncontrolled conditions, so we are in no position to relate the results found in the present paper to conditions for their production. To test the effect of comparable text awareness to translation, an ideal follow-up study ought to be more controlled, with one group working directly with the translation without comparable texts, the other with such texts presented to them before they start translating. It would be expected that the two groups, given that they have the same professional background, would come out differently with respect to the textual features of their end products.

DATA

- Bråten, Stein. 1996. Videoanalyser av spedbarnet I samspill bidrar til å oppheve et modellmonopol. In H. Holter and R. Kalleberg (eds.), Kvalitative metoder i samfunnsforskning, 165-191. Oslo: Universitetsforlaget.

- Bråten, Stein. 2004. Kommunikasjon og samspill, fra barndom til alderdom. Chapter 2. Oslo: Universitetsforlaget.

- The Multitranslation Corpus in the OMC. 1997-2008. http: //www . hf . uio . no/ilos/english/services/omc/.

- Smith, Lars Smith. 2002. Felles Oppmerksomhet I Spedbarnsalderen og Senere Språkferdigheter. Nordisk Tidsskrift for Spesialpedagogikk 02-03. 
- Trevarthen, Colwyn. 1979. Communication and Cooperation in Early Infancy: a Description of Primary Intersubjectivity. In M. Bullowa (ed.), Before Speech: The Beginning of Human Communication, 321-347. Cambridge: Cambridge University Press.

\section{REFERENCES}

Andersen, Øyvin. 2007. Deverbal nouns, lexicalization and syntactic change. Nordic Journal of Linguistics 30. 55-86.

Blum-Kulka, Shoshana. 1986. Shifts of Cohesion and Coherence in Translation. In Shoshana Blum-Kulka (ed.), Interlingual and Intercultural Communication, 17-35. Narr: Tübingeni.

Grimshaw, Jane. 1990. Argument Structure. Cambridge, MA: MIT Press.

House, Juliane. 2001. How do we Know when a Translation is Good. In E Steiner \& C. Yallop (eds.), Exploring Translation and Multilingual Text Production Beyond Content, 33. Berlin: Mouton de Gruyter.

Johansson, Stig. 2004. Why Change the Subject? Target 16(1). 29-52.

McNally, Louise \& M. Teresa Espinal. 2011. Semantic diversity in event-related nominals. In N. Pomino \& E. Stark (eds.), Proceedings of the V NEREUS Ineternational Workshop "Mismatches in Romance" 125, 1-12. Fachbereich Sprachwissenschaft, Universität Konstanz.

Nordrum, Lene. 2007. English Lexical Nominalizations in a Swedish-Norwegian Contrastive Perspective. Sweden: Gothenburg University dissertation.

Schleppegrell, Mary. 2006. The linguistic features of Advanced Language use. The Grammar of Exposition. In Heidi Byrnes (ed.), Advanced Language Learning: The Contribution of Halliday and Vygotsky, 134-146. London: Continuum.

Teich, Elke. 2000. Cross Linguistic Variation in System and Text. Berlin: Mouton de Gruyter.

Toury, Gideon. 1995. Descriptive translation Studies and Beyond. John Benjamins.

Venuti, Lawrence. 2004. Translation, Community, Utopia. In Lawrence Venuti (ed.), The Translation Studies Reader, 482-502. London and new York: Routledge. 
AUTHOR CONTACT INFORMATION

Bergljot Behrens

Department of Literature, Area Studies and European Languages

University of Oslo

Norway

bergljot.behrens@ilos.uio.no 